\title{
Effect of salt stress-tolerant bacterial endophytes from Bougainvillea glabra on the growth of Triticum aestivum L. var. HD 2687 and Zea mays var. PSCL-4642
}

\author{
ARUN KARNWAL \\ School of Bioengineering and Biosciences, Lovely Professional University, Phagwara, India
}

\begin{abstract}
Wheat and corn crops contribute to the food security of humans by providing a nutrient-rich diet. However, their production in abiotic stress conditions such as salinity is limited. Endophytes exert a beneficial effect on plants through the decomposition of organic materials for smooth absorption, detoxification, and reduction of the effect of phytopathogenic microorganisms by increasing the immunity of host plants to resist phytopathogens and through nutrient deposition in plants responsible for reducing salt stress. The present study aimed to evaluate the $\mathrm{NaCl}$ tolerance efficiency of Triticum aestivum L. var. HD 2687 and Zea mays var. PSCL-4642 cultivars at the germination stage after inoculation with salt-tolerant bacterial endophyte BoG121 isolated from Bougainvillea glabra. The seeds of both crops were tested for percentage of seed germination with/without bacteria at 50, 100, 150 , and $200 \mathrm{mM} \mathrm{NaCl}$ concentrations. The BoGl21 isolate induced a significant increase in radicle length in corn $(25.6 \mathrm{~mm})$ as compared to that in wheat $(10.3 \mathrm{~mm})$ at $50 \mathrm{mM} \mathrm{NaCl}$. However, at $100 \mathrm{mM} \mathrm{NaCl}$, the radical length of wheat and corn seedlings was $5 \mathrm{~mm}$ and $8.8 \mathrm{~mm}$, respectively. Inoculation of maize and wheat with the bacterial isolate significantly increased the plumule length of the germinated seeds as compared to that of controls. BoGl21 increased the plumule length of wheat as compared to that of the control seeds by $31.9,11.7$, and $4.8 \mathrm{~mm}$ at 50,100 , and $150 \mathrm{mM}$ salinity stress, respectively. Inoculation of corn seeds with BoGl21 at the tested $\mathrm{NaCl}$ levels $(50,100$, and $150 \mathrm{mM} \mathrm{NaCl})$ increased the plumule length of the germinated seeds by $33.1,22,13.2$, and $3.2 \mathrm{~mm}$, respectively. The current research results support the hypothesis that bacterial endophytes could be beneficial to minimize the toxicity of saline stress on wheat and corn at the time of germination.
\end{abstract}

Key words: Bougainvillea glabra, $\mathrm{NaCl}$, plant growth, seed germination, saline stress

\section{Introduction}

Every living being on the Earth is dependent on plants for their primary needs such as oxygen and food (Macauley, 2015). More than $90 \%$ of global nutrition comes from 12 crop varieties and 14 livestock species (FAO, 2009; Macauley, 2015). Wheat, rice, and corn are primary energy-providing crops for more than $50 \%$ of the global population (Myresiotis et al., 2015). Significant challenges to the current agricultural system, namely abiotic stresses due to climate change, affect soil salinity which has been widely documented to have an adverse impact on food security (Nehra et al., 2016). An increase in soil salinity is because of an increase in environmental temperature that leads to loss of moisture from the soil. This in turn elevates $\mathrm{NaCl}$ levels in the soil, thereby transforming fertile fields to arid lands. It should be emphasised that an increase in soil salinity retards plant growth, reduces product yield and flowering, and reduces the process of pollination (Yasin et al., 1998). Increased levels of salinity may cause ionic and osmotic stresses that negatively affect plant growth. Changes in osmotic pressure may lead to reduced cell turgor pressure due to changes in the water balance inside and outside of the cells. This in turn reduces cell elongation and cell division rates (Kumar and Verma, 2018).

\footnotetext{
* Corresponding author: School of Bioengineering and Biosciences, Lovely Professional University, Jalandhar-Delhi G.T. Road, National Highway 1, Phagwara, Punjab 144411, India; e-mail: arunkarnwal@gmail.com
} 
In the natural habitat, plants share a considerable amount of space and nutrients with many microorganisms. This nutrient-rich habitat is highly conducive for initiating positive mutual interactions between plants and microorganisms (Sarkar et al., 2018). These microorganisms (plant growth-promoting bacteria - PGPB) have various biochemical pathways such as deaminase activity, nodule formation, siderophore production, organic acid production, and other physiological activities that help the plants to bear stress (Ullah et al., 2019). PGPB are usually linked with various plant varieties and are typically found in various conditions. One of the most extensively examined class of PGPB are plant growthpromoting rhizobacteria (PGPR) found on root surfaces as well as on strongly adhering soil interface (Perrig et al., 2007). Regardless of the diverse environmental availability, free-living rhizobacteria and symbiotic bacteria utilize several identical mechanisms to enhance plant development and to manage phytopathogens (Karnwal and Kaushik, 2011). Many researchers (Tak et al., 2013; Haiyambo et al., 2015; Carlos et al., 2016) have reported that PGPR are ineffective under sudden changes in environmental conditions, namely stress conditions. Therefore, stress resistance is an important parameter when formulating microbial inoculants (Karnwal and Dohroo, 2018). These microorganisms can be used to reduce saline stress in plants and to restore salinity-prone lands for cultivation (Vejan et al., 2016; Etesami and Maheshwari, 2018; Abedinzadeh et al., 2019). Endophytic bacteria are the plant beneficial bacteria that thrive inside plants and can improve plant growth under normal and challenging conditions. They can benefit host plants directly by improving plant nutrient uptake and by modulating growth- and stressrelated phytohormones (Taghavi et al., 2015). Indirectly, endophytic bacteria can improve plant health by targeting pests and pathogens with antibiotics, hydrolytic enzymes, and nutrient limitation and by priming plant defences (Chauhan et al., 2016). Endophytes also have a beneficial effect on plants through the decomposition of organic materials for smooth absorption, detoxification, and reduction in the effect of phytopathogenic microorganisms by increasing the immunity of host plant to resist phytopathogens and through nutrient deposition in plants responsible for reducing salt stress (Yadav et al., 2011; Kumar et al., 2012; Karnwal, 2017). The most commonly found genera of bacterial endophytes are Microbacterium, Pseudomonas, Burkholderia, Stenotrophomonas, Bacillus, Pantoea, and Micrococcus (Almaghrabi et al., 2013)

Plant species effectively adapt and revolutionise themselves by using various strategies (through nutrient uptake and ionic balance, plant physiological response, antioxidant defence response, and proline accumulation) to overcome salt toxicity. Bougainvillea is a genus that grows and flourishes in saline areas (Jasim et al., 2015). It is a drought-tolerant, salt-tolerant, and wind-resistant plant (Islam et al., 2016; Abarca-Vargas and Petricevich, 2018). Bougainvillea glabra is a species that flourishes in well-drained, acidic soils with $\mathrm{pH}$ 5.5-6.0 and is not able to grow in soils which are persistently wet. B. glabra was used in the present study to isolate salt stress-tolerant bacterial endophytes that were further tested on wheat (Triticum aestivum L. var. HD 2687) and corn (Zea mays var. PSCL-4642).

\section{Materials and methods}

\section{Isolation of bacterial endophytes}

Endophytic bacteria were isolated from the leaves of B. glabra growing at Bhojia Institute of Life Sciences, Budh, Baddi, Himachal Pradesh, India (located at latitude 30.952802 and longitude 76.776914 ). The samples were thoroughly cleaned and sterilised (Karnwal, 2017) and then aseptically shredded $\left(0.5 \mathrm{~cm}^{2}\right.$ size $)$ before placing them on modified nutrient agar medium (NAM) enriched with $4 \%$ salt $(\mathrm{NaCl})$. The plates were incubated for up to $72 \mathrm{~h}$ at $28 \pm 1^{\circ} \mathrm{C}$ in dark. Individual bacterial colonies that developed around the inoculated leaf samples were assessed for their characteristics and appearance. The pure cultures (overnight grown bacterial cultures) were subsequently preserved with $30 \%$ glycerol and kept at $-80^{\circ} \mathrm{C}$ until further examination.

\section{Stress tolerance screening of bacterial isolates}

Salinity tolerance of the isolated bacterial species was investigated on NAM supplemented with different $\mathrm{NaCl}$ concentration: $5 \%(0.86 \mathrm{M}) ; 7 \%(1.2 \mathrm{M}) ; 8.5 \%(1.46 \mathrm{M})$; $10 \%(1.71 \mathrm{M})$; and $12 \%(2.054 \mathrm{M})$. The plates were streaked with bacterial culture and incubated in a BOD incubator for $48 \mathrm{~h}$ at $28 \pm 1^{\circ} \mathrm{C}$. Bacterial isolates that grew above $4 \% \mathrm{NaCl}$ were documented as salt stress-resistant and tested in vitro for temperature stress $\left(25-40^{\circ} \mathrm{C}\right), \mathrm{pH}$ stress $(5-8)$, and plant growth promotion (PGP) attributes (Karnwal, 2019). 
The results of the stress study on bacterial growth were recorded as binary numbers (growth " 1 " and no growth "0") and were analysed using PAST 3.22 software.

\section{Screening for PGP traits}

\section{Solubilisation of phosphate}

Phosphate solubilisation assay was conducted by applying spot inoculation of each bacterial isolate on modified Pikovskaya's agar (HiMedia) and presented in the form of solubilisation index (SI) (Karnwal, 2017). Clear halo zones around the bacterial growth were considered as positive for phosphate solubilisation and quantified using the following equation (Edi-Premono et al., 1996):

Phosphate solubilization index $(\mathrm{SI})=$

$$
=\frac{\text { (colony diameter }+ \text { halo zone diameter })}{\text { colony diameter }}
$$

The inorganic phosphate liquefaction was measured in vitro by calculating existing liquid phosphate in $0.5 \%$ tri-calcium phosphate (TCP)-supplemented media. Pikovskaya's broth was inoculated with isolated salt-tolerant bacteria in triplicate. All flasks were incubated at $28 \pm 1^{\circ} \mathrm{C}$ on a rotary shaker incubator for $120 \mathrm{~h}$ at $180 \mathrm{rpm}$ and then centrifuged for $10 \mathrm{~min}$ at $11180 \mathrm{~g}$. Phosphate in the culture medium was measured using the phosphomolybdate method (Vaishnav et al., 2016).

\section{IAA-like auxin production}

IAA production was measured on DF (Dworkin and Foster) medium enriched with 0.1\% L-tryptophan using Van Urk Salkowski reagent by Salkowski's method (Armada et al., 2016). The bacterial isolates (100 $\mu$ l) were incubated in DF medium supplemented with L-tryptophan for $48 \mathrm{~h}$ at $28 \pm 1^{\circ} \mathrm{C}$. The culture broth was centrifuged at $11963 \mathrm{~g}$, and $1 \mathrm{ml}$ of supernatant with $2 \mathrm{ml}$ of Salkowski reagent $\left(2 \% 0.5 \mathrm{FeCl}_{3}\right.$ in $\left.35 \% \mathrm{HClO}_{4}\right)$ was incubated in the test tube. This mixture was left without any disturbance for 30 minutes in the dark at room temperature. The optical density (OD) was recorded at $530 \mathrm{~nm}$, and the amount of IAA-like auxins was measured as $\mu \mathrm{g} / \mathrm{ml}$ against the non-inoculated control. A standard curve of various concentrations (range $0-250 \mu \mathrm{g} / \mathrm{ml}$ ) of pure IAA (Merck, Frankfurt, Germany) was prepared by plotting IAA concentration based on the optical density (Almaghrabi et al., 2013).

\section{1-Aminocyclopropane-1-carboxylate (ACC) deaminase assay}

The ACC deaminase assay for salt-tolerant isolates was performed on DF salt minimal medium (Dworkin and Foster, 1958) supplemented with ACC as the sole nitrogen source. DF agar plates inoculated with bacteria were incubated for $48 \mathrm{~h}$ at $28 \pm 1^{\circ} \mathrm{C}$. The appearance of a bacterial colony after incubation was considered as positive.

\section{Siderophore production}

Chrome-azurol S (CAS) medium was used to confirm the siderophore production potential of bacterial isolates (Schwyn and Neilands 1987). Bacterial culture after $24 \mathrm{~h}$ incubation was inoculated on CAS agar and incubated for $48-72 \mathrm{~h}$ at $28 \pm 1^{\circ} \mathrm{C}$. Colour change of CAS agar medium from blue to orange or yellow around the bacterial growth confirmed siderophore production.

\section{HCN determination}

The capability of bacterial isolates to produce $\mathrm{HCN}$ was tested according to Akter et al. (2016) with some modifications. The NAM amended with glycine $(4.4 \mathrm{~g} / \mathrm{l})$ was streaked with bacterial isolates. A sterile Whatman No. 1 filter paper was placed on the upper lid of the Petri plate saturated with picric acid solution (2.5 g of $\left(\mathrm{O}_{2} \mathrm{~N}\right)_{3} \mathrm{C}_{6} \mathrm{H}_{2} \mathrm{OH} ; 12.5 \mathrm{~g}$ of $\mathrm{Na}_{2} \mathrm{CO}_{3}, 1000 \mathrm{ml}$ of distilled $\mathrm{H}_{2} \mathrm{O}$ ). Petri plates sealed with parafilm were incubated at $28 \pm 1^{\circ} \mathrm{C}$. The change of colour (colour of Whatman No. 1 filter paper saturated with picric acid solution) to light/moderate/intense brown was considered as positive for $\mathrm{HCN}$.

\section{Colonisation ability}

Root colonisation of BoGl21 was tested with wheat and corn seeds as described by Silva et al. (2003). The seeds were obtained from the Indian Agricultural Research Institute (IARI), Pusa, Delhi, India, and sterilised according to Karnwal (2019). Surface-sterilised seeds were immersed and left for $12 \mathrm{~h}$ in bacterial culture suspension (two-day-old bacterial growth) with $9 \log 10$ $\mathrm{CFU} \mathrm{ml} \mathrm{l}^{-1}$ and then placed in culture tubes containing 0.05\% Phytagel (Sigma-Aldrich) for germination. The bacterial isolate BoGl21 was tested in three replicates (a replicate was considered as one seed in a tube). Change in the opacity of Phytagel near roots was considered as bacterial root colonisation. 


\section{Effect of NaCl Stress on Seed Germination}

Effect of different concentrations of $\mathrm{NaCl}$ on seed germination was analysed by placing 10 surface-sterilised plant seeds in a petri dish lined with wetted Whatman No. 1 filter paper ( $5 \mathrm{ml}$ of $0,50,100$, and $150 \mathrm{mM}$ ) of sterile $\mathrm{NaCl}$ solution. For each treatment, Petri plates were incubated in a plant growth chamber at $28^{\circ} \mathrm{C}$, and the number of germinated seeds was recorded for four subsequent days after $24 \mathrm{~h}$. All the experiments were conducted in the dark and in triplicate.

\section{Seed inoculation}

The bacterial suspensions were adjusted at 0.5 McFarland (cell density: $8 \log 10 \mathrm{CFU} \mathrm{ml}^{-1}$ at $600 \mathrm{~nm}$ ). McFarland Standard was considered as the benchmark to control the final turbidity of bacterial culture to ensure that it is in a specific range $(0.5 \mathrm{McFarland}=$ $1.5 \times 10^{8} \mathrm{CFU} \mathrm{ml}{ }^{-1} ; 1 \mathrm{McF}$ arland $=3.0 \times 10^{8} \mathrm{CFU} \mathrm{ml}^{-1}$; 2.0 McFarland $=6.0 \times 10^{8} \mathrm{CFU} \mathrm{ml}^{-1} ; 3.0 \mathrm{McF}$ arland $=$ $9.0 \times 10^{8} \mathrm{CFU} \mathrm{ml}^{-1}$ ).

Surface-sterilised seeds were immersed in bacterial suspension and rotated at $150 \mathrm{rpm}$ for $2 \mathrm{~h}$ at $28^{\circ} \mathrm{C}$. Subsequently, the seeds were air-dried in a laminar airflow hood for $60 \mathrm{~min}$. Ten seeds per plant were placed on sterile moistened Whatman No. 1 filter paper (wetted with $5 \mathrm{ml}$ of sterile distilled water). All trials were conducted in triplicate.

\section{Seed inoculation under salinity conditions}

Effect of the bacterial isolate BoGl21 on seed germination and under different salinity conditions was determined with different $\mathrm{NaCl}$ concentrations (50, 100, 150 , and $200 \mathrm{mM})$. Ten surface-sterilised bacterial inoculated seeds were separated, and each was placed in a Petri dish lined with sterile Whatman No. 1 filter paper. Sterile distilled water was used instead of bacterial suspension to serve as control. Five millilitres of sterile $50,100,150$, and $200 \mathrm{mM} \mathrm{NaCl}$ solution was used for maintaining salinity and moisture conditions during the experiment. The germination percentage (\%) was calculated based on Kader's equation:

Germination $[\%]=\frac{\text { number of germinated seeds }}{\text { total number of seeds }} \times 100$

\section{Characterisation and identification of the bacterial isolate}

Biochemical identification of BoGl21 was carried out according to Bergey's Manual of Determinative Bacterio- logy (Holt et al., 1994). For phenotypic characterisation, Gram's staining, motility testing, and endospore staining were performed (Karnwal and Kaushik, 2011). Phylogenetic analysis and $16 \mathrm{~S}$ ribosomal RNA sequencing were carried out for the bacterial isolate BoGl21 according to Karnwal (2019) by using the DNeasy-Plant Mini Kit (Qiagen, USA) and universal16S rRNA gene (rDNA) bacterial primers $534 \mathrm{r}\left(5^{\prime}-\mathrm{ATTACCGCGGCTGCTGG-3^{ \prime } )}\right.$ and U1517R (5' - ACGGCTACCTTGTTACGACTT-3').

\section{Trial design and statistical analysis}

All trials were performed in a randomised block design. Numerical data generated from seed germination and growth promotion experiments were subjected to analysis of variance (ANOVA). Fisher's significant difference (LSD) test at $P$ values of 0.05 was used to compare the mean of the treatments.

\section{Results and discussion}

\section{Isolation of bacterial endophytes}

In a natural environment, plants have to manage various biotic and abiotic stresses (Balseiro-Romero et al., 2017). Abiotic stresses refer to inanimate components associated with the environment, such as nutrients, salt concentration, water availability, temperature change, and $\mathrm{pH}$, which directly influence plant growth in the agricultural field (Kumar and Verma, 2018). In the present study, 28 bacterial endophytes were screened from the leaf samples of B. glabra (designated as BoGl1 to BoGl28). Four isolates (BoG15, BoG18, BoGl21, and BoG126) were found to have salt-tolerant ability and were subcultured in pure form at $5 \% \mathrm{NaCl}$-supplemented NAM for further studies. The characteristics of the four isolates are given in Table 1. All four isolates had colonies from irregular to circular ones (see Table 1).

Endophytic microorganisms rely on natural host plants to survive. Several researchers (Khalifa et al., 2016; Nascimento et al., 2016) have reported less diverse endophytic bacteria in plants $(4 \log 10$ to $8 \log 10$ $\mathrm{CFU} / \mathrm{g}$ of plant tissue) than rhizospheric bacteria (6 $\log 10$ to $9 \log 10 \mathrm{CFU} / \mathrm{g}$ of soil). On the basis of the results of previous studies (Mahmood et al., 2016; Etesami and Maheshwari, 2018; Noori et al., 2018), the use of beneficial microorganisms in agricultural fields to increase salt-stress tolerance of plants has been proposed. In the present study, the four bacterial isolates 
Table 1. Microscopic and macroscopic characteristics of the isolated bacterial cultures

\begin{tabular}{l|c|c|c|c|c}
\hline $\begin{array}{c}\text { Bacterial } \\
\text { isolate }\end{array}$ & Shape & Colour & Margin & Elevation & $\begin{array}{c}\text { Gram } \\
\text { stain }\end{array}$ \\
\hline BoG15 & rod & pale yellow & circular & convex & - \\
\hline BoG18 & cocci & yellow & irregular & raised & - \\
\hline BoG121 & rod & whitish & irregular & raised & + \\
\hline BoG126 & cocci & whitish & circular & raised & - \\
\hline
\end{tabular}

Table 2. Screening of bacterial isolates for phosphate solubilisation ability

\begin{tabular}{c|c|c|c|c}
\hline \multirow{2}{*}{$\begin{array}{c}\text { Bacterial } \\
\text { isolate }\end{array}$} & \multicolumn{2}{|c|}{ Phosphate solubilization efficiency } & $\begin{array}{c}\text { Phosphate } \\
\text { solubilization } \\
\text { index }\end{array}$ & $\begin{array}{c}\text { Phosphate } \\
\text { solubilization } \\
{[\mu \mathrm{m} / \mathrm{ml}]}\end{array}$ \\
\hline BoG15 & $10 \pm 0.02$ & 0 & $1.00 \pm 0.02$ & 0 \\
\hline BoG18 & $1 \pm 0.07$ & 0 & $1.00 \pm 0.03$ & 0 \\
\hline BoGl21 & $6 \pm 0.12$ & $38 \pm 0.08$ & $7.33 \pm 0.01$ & $214.59 \pm 0.21$ \\
\hline BoGl26 & $1.5 \pm 0.03$ & $8 \pm 0.02$ & $6.33 \pm 0.05$ & $103.83 \pm 0.04$ \\
\hline
\end{tabular}

Values are the mean of 3 replicates \pm standard error of mean

Table 3. Screening profile of bacterial isolates for various PGP characteristics

\begin{tabular}{l|c|c|c|c}
\hline $\begin{array}{c}\text { Bacterial } \\
\text { isolate }\end{array}$ & $\begin{array}{c}\text { IAA-like auxin } \\
\text { production } \\
{[\mu \mathrm{g} / \mathrm{ml}]^{*}}\end{array}$ & $\begin{array}{c}\mathrm{HCN} \\
\text { production }\end{array}$ & $\begin{array}{c}\text { Siderophore } \\
\text { production zone } \\
{[\mathrm{mm}]^{*}}\end{array}$ & $\begin{array}{c}\text { ACC } \\
\text { deaminase } \\
\text { activity }\end{array}$ \\
\hline BoG15 & $0.26 \pm 0.01$ & ++ & $1.8 \pm 0.47$ & - \\
\hline BoG18 & $2.7 \pm 1.51$ & - & $8.2 \pm 1.62$ & - \\
\hline BoGl21 & $28.1 \pm 1.38$ & +++ & $18.8 \pm 1.82$ & +++ \\
\hline BoG126 & $6.62 \pm 2.10$ & + & $8.1 \pm 0.61$ & + \\
\hline
\end{tabular}

* mean of 3 replicates \pm standard error of mean;

+++- strong action, ++- modest action, +- weak action, $(-)-$ no action

were tested for their PGP traits: IAA production, phosphate liquefaction, siderophore production, ACC deaminase activity, and hydrogen cyanide production.

Phosphorus is an essential macronutrient required by all living organisms. Plants require it in small amounts although its critically low availability could lead to deficiency and thus adversely affect their growth (Karnwal, 2017). The required amount of phosphorus for optimal growth ranges from $25 \mu \mathrm{mol} / 1$ to $30 \mu \mathrm{mol} / 1$, but the actual amount of phosphorus available in most soil types ranges only from $1 \mu \mathrm{mol} / 1$ to $1.7 \mu \mathrm{mol} / 1$ (Perrig et al., 2007). Several researchers (Perrig et al., 2007; Masciarelli et al., 2014) have reported that plants use soil bacteria for liquefaction of mineral phosphates into a utili- sable form. The current study found only two isolates that showed bright areas surrounding the bacterial growth with a diameter ranging from 8 to $38 \mathrm{~mm}$ and phosphate solubilisation index ranging from 6.33 to 7.33, thus indicating positive results (Table 2). The phosphate-solubilising efficiency of all four isolates chosen for testing in $0.5 \%$ tri-calcium phosphate supplemented with Pikovskaya's broth showed that two bacterial isolates successfully liquefied mineral phosphate in the inoculated broth (Table 2). Phosphate solubilising bacteria (PSB) BoGl21 and BoGl26 were found to solubilize phosphate to the level of $214.59 \mu \mathrm{g} / \mathrm{ml}$ and $103.83 \mu \mathrm{g} / \mathrm{ml}$ soluble phosphate, respectively, in the broth after $48 \mathrm{~h}$ of incubation. 
The phosphate solubilising efficiency of all four strains is shown in Table 2. Inorganic phosphate solubilisation by microorganisms is important for crop growth as a source of nourishment. Earlier studies have reported the application of numerous soil bacterial genera, namely Achromobacter, Pseudomonas, Flavobacterium, Enterobacter, Serratia, Bacillus, Mycobacterium, Erwinia, Agrobacterium, and Escherichia, as phosphate solubilisers (Haiyambo et al., 2015; Carlos et al., 2016).

Production ofIAA, which is important for plant growth, is one of the most critical characteristics of a wide variety of soil microorganisms. IAA is a growth hormone associated with rhizome propagation, plant cell proliferation, and cell duplication (Karnwal and Dohroo, 2018). In the present study, all the four isolates were analysed for IAA production (namely availability of L-tryptophan), and they all showed positive attributes for IAA production ranging from $0.26 \mu \mathrm{g} / \mathrm{ml}$ to $28.1 \mu \mathrm{g} / \mathrm{ml}$ (see Table 3). The isolate BoGl21 produced the maximum amount of IAA of $28.1 \mu \mathrm{g} / \mathrm{ml}$. Strains BoGl5, BoGl8, and BoGl26 produced lower amounts of IAA $(0.26 \mu \mathrm{g} / \mathrm{ml}, 2.7 \mu \mathrm{g} / \mathrm{ml}$, and $6.63 \mu \mathrm{g} / \mathrm{ml}$, respectively).

Karnwal (2019) reported the significance of rhizocompetent stress-resistant microorganisms with diverse functions that are primarily responsible for the elimination of salt anxiety in crops. The biosynthesis of iron scavenger siderophores is an important function of PGPRs (Chauhan et al., 2016). It promotes plant development by increasing nutrient supply for the plant while reducing iron supply for soil-borne phytopathogens. In the current study, three isolates (BoGl5, BoGl21, and BoGl26) showed positive results for $\mathrm{HCN}$, all the isolates showed positive results for siderophore production, while only two isolates (BoGl21 and BoGl26) showed ACC deaminase activity (see Table 3 ).

The PGPRs in soil produce ACC deaminase and promote plant growth; they also protect the plant against abiotic (drought, salt, flooding, and inorganic and organic contaminants) (Benidire et al., 2016) and biotic stresses (bacterial and fungal pathogens). These secondary metabolites have an immediate effect on shoot, root, and seed growth of various crops.

\section{Screening for stress tolerance}

Microorganisms use various mechanisms to enable them to survive under stress environment. Numerous bacterial genera such as Azotobacter, Bacillus, Pseudo- monas, and Rhizobium are competent to withstand abiotic stresses by synthesising a significant amount of exopolysaccharides (EPS) (Torres et al., 2019). In the present study, the bacterial isolates BoGl5, BoGl8, BoGl21, and BoGl26 were assessed at varying levels of salinity, $\mathrm{pH}$, and temperature. The salt stress results revealed that the selected isolates could tolerate $\mathrm{NaCl}$ concentration of higher than $5 \%$. The BoGl21 isolate showed good growth on media containing $5 \%(0.86 \mathrm{M}), 7 \%(1.2 \mathrm{M})$, and $8.5 \%(1.46 \mathrm{M})$ salt concentration. In recent years, bacteria belonging to different genera such as Rhizobium, Bacillus, Pseudomonas, Burkholderia, Achromobacter, Methylobacterium, and Variovorax have been shown to exhibit good tolerance against different abiotic stresses (Passari et al., 2016). Such microorganisms can help to avoid environmental anxiety in farming and are potentially useful for decreasing soil salinity. In the current study, it was found that BoGl21 could tolerate a maximum of $10 \% \mathrm{NaCl}$ concentration, where it showed slow growth (growth was seen after 5 days of incubation), whereas at $12 \% \mathrm{NaCl}$ concentration, no growth was observed. Bacterial growth was observed at different $\mathrm{pH}$ values tested. The ideal $\mathrm{pH}$ for BoGl21 growth was 6 , although positive results were also noted at $\mathrm{pH} 5$ and 7. Temperature stress test showed that the bacterial isolate could grow in temperatures ranging from $25^{\circ} \mathrm{C}$ to $40^{\circ} \mathrm{C}$. A dendrogram created for the bacterial isolates by using UPGMA cluster analysis (similarity index: Euclidean) for stress tolerance at different levels of salinity, temperature, and $\mathrm{pH}$ showed two clusters: cluster 1 included 3 isolates (BoGl5, BoGl21, and BoGl26) and cluster II included 1 isolate (BoGl8) as shown in Figure 1.

\section{Root colonisation}

It was found that the isolate BoGl21 could colonize the roots of wheat and corn seedlings. The bacterial strain formed dense opaque zones around radicles and regions adjacent to the roots. This indicated root colonisation.

\section{Effect of saline condition on seed germination}

Seed germination efficiency of wheat and corn seeds was tested at different $\mathrm{NaCl}$ concentrations $(0,50,100$, 150 , and $200 \mathrm{mM})$. A $100 \%$ seed germination was recorded at $50 \mathrm{mM} \mathrm{NaCl}$ concentration for both experimental plants. At higher $\mathrm{NaCl}$ concentration, the percentage of seed germination was reduced for both types 


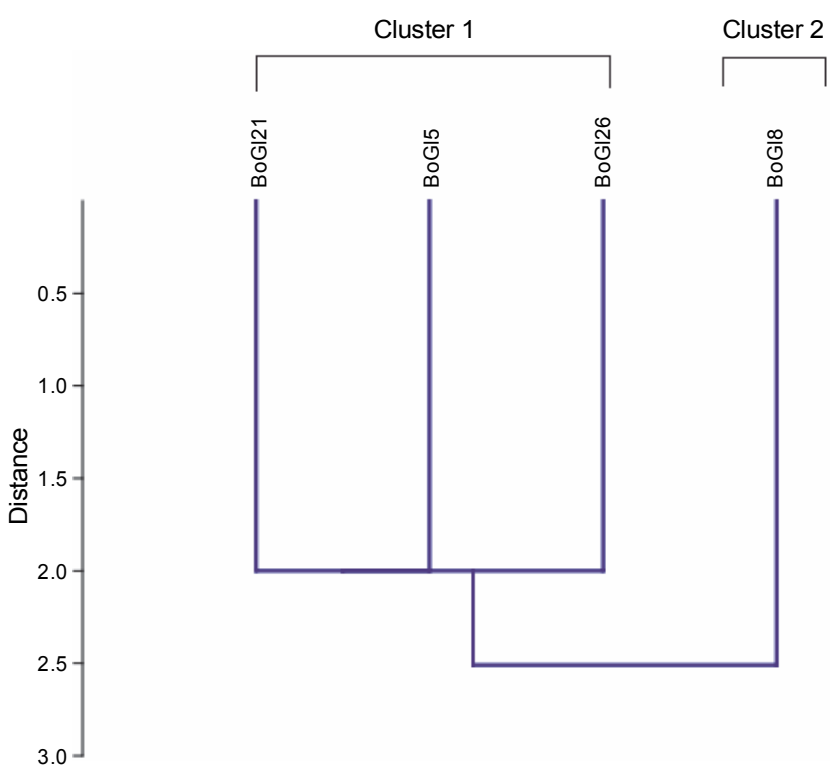

Fig. 1. Dendrogram based on UPGMA cluster analysis (similarity index: Euclidean) by using PAST software 3.22 for salttolerant isolates of Bougainvillea glabra using growth pattern data for different stress levels (salinity, temperature, and $\mathrm{pH}$ stress). Of all the screened four isolates, BoGl21 showed the most prominent PGP characteristics and higher salt tolerance activity. Therefore, only the BoGl21 strain was selected for further studies: colonisation, seed inoculation, seed inoculation under salinity conditions, and bacterial identification

Table 4. Seed germination percentage of wheat and corn under various $\mathrm{NaCl}$ concentrations after 4 days of incubation

\begin{tabular}{l|c|c}
\hline \multirow{2}{*}{$\begin{array}{c}\mathrm{NaCl} \text { concentration } \\
{[\mathrm{mM}]}\end{array}$} & \multicolumn{2}{|c}{ Seed germination [\%] } \\
\cline { 2 - 3 } & wheat & \multicolumn{1}{c}{ corn } \\
\hline Control & $100 \pm 0.30^{\mathrm{a}}$ & $100 \pm 1.21^{\mathrm{a}}$ \\
\hline 50 & $100 \pm 0.04^{\mathrm{a}}$ & $100 \pm 0.08^{\mathrm{a}}$ \\
\hline 100 & $78 \pm 0.70^{\mathrm{a}}$ & $82 \pm 0.02^{\mathrm{a}}$ \\
\hline 150 & $70 \pm 0.03^{\mathrm{a}}$ & $50 \pm 0.72^{\mathrm{b}}$ \\
\hline 200 & $30 \pm 0.24^{\mathrm{a}}$ & $8 \pm 1.32^{\mathrm{b}}$ \\
\hline
\end{tabular}

Values with different superscript letters in a column are significantly different $(P<0.05)$ and show the difference between control and $\mathrm{NaCl}$ treatments

of plants. At $100 \mathrm{mM}$ concentration, seed germination for wheat and corn was $78 \%$ and $82 \%$, respectively. Increased concentration of $\mathrm{NaCl}(150$ and $200 \mathrm{mM}$ ) showed $32 \%$ and $74 \%$ decline in corn seed germination as compared to that with $100 \mathrm{mM} \mathrm{NaCl}$ concentration, respectively. Furthermore, only $18 \%$ decline in seed germination was observed for wheat at $150 \mathrm{mM} \mathrm{NaCl}$ concentration as compared to that at $100 \mathrm{mM} \mathrm{NaCl}$ con- centration. At 150 and $200 \mathrm{mM} \mathrm{NaCl}$ concentrations, the percentage of seed germination was $40 \%$ and $42 \%$, respectively, for wheat and corn (Table 4).

\section{Seed inoculation under salinity condition}

Table 5 shows the results of the influence of salt stress on wheat and corn seed germination at different concentrations of $\mathrm{NaCl}$. A positive effect of the inoculated bacteria was noted on percentage seed germination as compared to the control. Strain BoGl21 showed better percentage of seed germination in wheat than in corn and control. The inoculation of BoGl21 in wheat showed $86 \%$ and $58 \%$ seed germination at 150 and $200 \mathrm{mM}$ salt concentrations, respectively, while in corn, $74 \%$ and $26 \%$ seed germination was noted at similar $\mathrm{NaCl}$ concentrations, respectively. These results confirmed the positive effect of bacterial inoculation on the germination of seeds under salinity stress (Table 5).

BoGl21 inoculation increased the radicle length of wheat seedlings significantly by 10.3 and $5 \mathrm{~mm}$ at 50 and $100 \mathrm{mM}$ salinity stress, respectively (Table 6). Similarly, the inoculation of corn seeds with BoGl21 increased the radicle length significantly at 50 and $100 \mathrm{mM}$ salinity stress by 25.6 and $8.8 \mathrm{~mm}$, respectively. However, the inoculation of seeds with the BoGl21 isolate did not show any increase in radicle length at higher level of salinity $(200 \mathrm{mM} \mathrm{NaCl})$ in both crops (Table 6$)$.

The inoculation of seeds with BoGl21 at $50 \mathrm{mM} \mathrm{NaCl}$ concentration increased the plumule length of wheat and corn germinated seeds by $31.9 \mathrm{~mm}$ for wheat and 33.1 $\mathrm{mm}$ for corn (Table 7). No plumule growth was observed at $200 \mathrm{mM} \mathrm{NaCl}$ for wheat inoculated with BoGl21, whereas for corn, a limited growth was observed at the same $\mathrm{NaCl}$ level. At $150 \mathrm{mM} \mathrm{NaCl}$ concentration, bacterial inoculation in corn showed a significant increase $(13.2 \mathrm{~mm})$ in the growth of plumule as compared to that of the control plant.

\section{Characterisation and identification of the bacterial isolate}

Earlier studies (Jasim et al., 2015; Passari et al., 2016; Karnwal 2019) found that endophytic bacteria such as Proteobacteria, Firmicutes, Actinobacteria, and Bacteroidetes are important for plant growth. The most common genera of bacterial endophytes are Microbacterium, Pseudomonas, Burkholderia, Stenotrophomonas, Bacillus, Pantoea, and Micrococcus (Taghavi et al., 2015; 
Table 5. Effect of bacterial inoculation on seed germination under various $\mathrm{NaCl}$ concentrations

\begin{tabular}{c|c|c|c|c}
\hline \multirow{2}{*}{$\begin{array}{c}\text { NaCl concentration } \\
{[\mathrm{mM}]}\end{array}$} & \multicolumn{2}{|c|}{ Seed germination \% for wheat } & \multicolumn{2}{c}{ Seed germination \% for corn } \\
\cline { 2 - 5 } & control & BoGl21 & control & BoGl21 \\
\hline 50 & $100 \pm 0.00^{\mathrm{a}}$ & $100 \pm 0.00^{\mathrm{a}}$ & $100 \pm 0.08^{\mathrm{a}}$ & $100 \pm 0.00^{\mathrm{a}}$ \\
\hline 100 & $78 \pm 0.70^{\mathrm{b}}$ & $100 \pm 0.00^{\mathrm{a}}$ & $82 \pm 0.02^{\mathrm{b}}$ & $100 \pm 0.00^{\mathrm{a}}$ \\
\hline 150 & $70 \pm 0.03^{\mathrm{c}}$ & $86 \pm 1.42^{\mathrm{b}}$ & $50 \pm 0.72^{\mathrm{c}}$ & $74 \pm 0.2^{\mathrm{b}}$ \\
\hline 200 & $30 \pm 0.24^{\mathrm{c}}$ & $58 \pm 0.02^{\mathrm{b}}$ & $12 \pm 1.32^{\mathrm{c}}$ & $26 \pm 2.12^{\mathrm{b}}$ \\
\hline
\end{tabular}

Values represented with superscript letters in a row are significantly different $(P<0.05)$ and show the difference between control and $\mathrm{NaCl}$ treatments

Table 6. Effect of endophytes on radicle length under various $\mathrm{NaCl}$ concentrations

\begin{tabular}{c|c|c|c|c}
\hline \multirow{2}{*}{\begin{tabular}{c}
$\mathrm{NaCl}$ \\
\multirow{2}{*}{$\begin{array}{c}\text { concentration } \\
{[\mathrm{mM}]}\end{array}$}
\end{tabular}} & \multicolumn{2}{|c|}{$\begin{array}{c}\text { Radicle length of wheat seedlings } \\
{[\mathrm{mm}]}\end{array}$} & \multicolumn{2}{c}{$\begin{array}{c}\text { Radicle length corn seedlings } \\
{[\mathrm{mm}]}\end{array}$} \\
\cline { 2 - 5 } & control & BoGl21 & control $^{\mathrm{b}}$ & BoGl21 \\
\hline 50 & $4.3 \pm 0.11^{\mathrm{c}}$ & $10.3 \pm 0.18^{\mathrm{b}}$ & $3.8 \pm 0.24^{\mathrm{b}}$ & $25.6 \pm 0.16^{\mathrm{a}}$ \\
\hline 100 & $3.7 \pm 0.03^{\mathrm{b}}$ & $5.0 \pm 0.05^{\mathrm{ab}}$ & $3.0 \pm 0.12^{\mathrm{a}}$ & $8.8 \pm 0.15^{\mathrm{a}}$ \\
\hline 150 & $0.0 \pm 0.0^{\mathrm{b}}$ & $1.8 \pm 0.2^{\mathrm{a}}$ & $0.0 \pm 0.0^{\mathrm{a}}$ & $4.2 \pm 0.14^{\mathrm{a}}$ \\
\hline 200 & $0.0 \pm 0.0^{\mathrm{a}}$ & $0.0 \pm 0.0^{\mathrm{a}}$ & $0.0 \pm 0.0^{\mathrm{a}}$ & $1.0 \pm 0.01^{\mathrm{a}}$ \\
\hline
\end{tabular}

Values represented with superscript letters in a row are significantly different $(P<0.05)$ and show the difference between control and $\mathrm{NaCl}$ treatments

Table 7. Effect of endophytes on plumule length under various $\mathrm{NaCl}$ concentrations

\begin{tabular}{c|c|c|c|c}
\hline \multirow{2}{*}{\begin{tabular}{c}
$\mathrm{NaCl}$ \\
\multirow{2}{*}{$\begin{array}{c}\text { concentration } \\
{[\mathrm{mM}]}\end{array}$}
\end{tabular}} & \multicolumn{2}{|c|}{$\begin{array}{c}\text { Plumule length of wheat seedlings } \\
{[\mathrm{mm}]}\end{array}$} & \multicolumn{2}{c}{$\begin{array}{c}\text { Plumule length of corn seedlings } \\
{[\mathrm{mm}]}\end{array}$} \\
\cline { 2 - 5 } & control $^{\mathrm{B}}$ & BoGl21 & control $^{\mathrm{B}}$ & BoGl21 \\
\hline 50 & $10.3 \pm 0.07^{\mathrm{b}}$ & $31.9 \pm 0.22^{\mathrm{a}}$ & $11.2 \pm 0.27^{\mathrm{b}}$ & $33.1 \pm 0.46^{\mathrm{a}}$ \\
\hline 100 & $8.0 \pm 0.32^{\mathrm{a}}$ & $11.7 \pm 0.07^{\mathrm{a}}$ & $9.2 \pm 0.16^{\mathrm{b}}$ & $22.0 \pm 1.24^{\mathrm{a}}$ \\
\hline 150 & $0.0 \pm 0.0^{\mathrm{b}}$ & $4.8 \pm 0.02^{\mathrm{ab}}$ & $0.0 \pm 0.0^{\mathrm{b}}$ & $13.2 \pm 0.06^{\mathrm{a}}$ \\
\hline 200 & $0.0 \pm 0.0^{\mathrm{a}}$ & $0.0 \pm 0.0^{\mathrm{a}}$ & $0.0 \pm 0.0^{\mathrm{a}}$ & $3.8 \pm 0.08^{\mathrm{a}}$ \\
\hline
\end{tabular}

Values represented with superscript letters in a row are significantly different $(P<0.05)$ and show the difference between control and $\mathrm{NaCl}$ treatments

Heydarian et al., 2016). Microscopic, biochemical, and molecular methods were used to identify and characterise the BoGl21 bacterial isolate. Microscopy results revealed that the bacterial isolate BoGl21 was rod-shaped bacilli and gram-positive in nature.

Molecular characterisation of the bacterial isolate was performed by the $16 \mathrm{~S}$ rDNA sequencing method. The 16S rRNA gene sequence of BoGl21 showed 90.96\% identity with that of Bacillus aerius strain $24 \mathrm{~K}$ and Bacillus licheniformis strain DSM 13 (90.45\%) as shown in Figure 2. The phylogenetic tree for BoGl21 was constructed using MEGA X software as shown in Figure 2.

\section{Conclusions}

The present study confirmed the growth of wheat and corn in saline conditions in the presence of salinitytolerant bacterial endophytes. Inoculation of wheat and maize with the bacterial isolate showed positive results in terms of increase in the percentage of seed germination, plumule length, and radicle length. These improvements in plant growth characteristics were related to phytohormone production (auxins-IAA), phosphate liquefaction, siderophore production, ACC deaminase activity, and $\mathrm{HCN}$ production, which suggested that salinity 


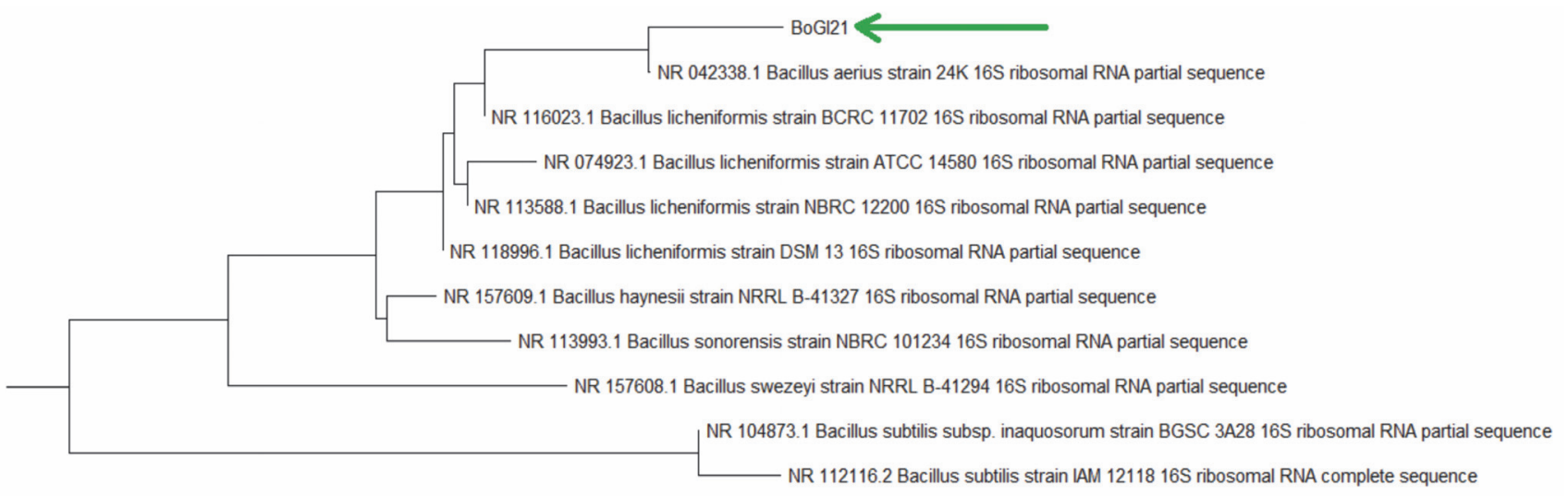

Fig. 2. Phylogenetic tree created for the isolate BoGl21 by using MEGA X software

stress-tolerant bacteria were helpful and beneficial for enhancing the growth of wheat and corn. The results of the present study are useful to evaluate the possibilities of using salt stress-tolerant bacterial endophytes in wheat and corn varieties grown in the Himachal region under field conditions.

\section{Acknowledgement}

The authors are grateful to Bhojia Institute of Life Sciences, Budh, Baddi, Himachal Pradesh, India, for technical support to complete this study and for unlimited help at all steps of the study.

\section{References}

Abarca-Vargas R., Petricevich V.L. (2018) Bougainvillea genus: a review on phytochemistry, pharmacology, and toxicology. Evid. Based Compl. Alternat. Med. Article ID 9070927.

Abedinzadeh M., Etesami H., Alikhani H.A. (2019) Characterization of rhizosphere and endophytic bacteria from roots of maize (Zea mays L.) plant irrigated with wastewater with biotechnological potential in agriculture. Biotechnol. Rep. (Amst) 21: e00305.

Almaghrabi O.A., Massoud S.I., Abdelmoneim T.S. (2013) Influence of inoculation with plant growth promoting rhizobacteria (PGPR) on tomato plant growth and nematode reproduction under greenhouse conditions. Saudi J. Biol. Sci. 20(1): 57-61.

Armada E., Probanza A., Roldan A., Azcon R. (2016) Native plant growth promoting bacteria Bacillus thuringiensis and mixed or individual mycorrhizal species improved drought tolerance and oxidative metabolism in Lavandula dentata plants. J. Plant. Physiol. 192: 1-12.

Balseiro-Romero M., Gkorezis P., Kidd P.S., Van Hamme J., Weyens N., Monterroso C., Vangronsveld J. (2017) Use of plant growth promoting bacterial strains to improve cytisus striatus and lupinus luteus development for potential application in phytoremediation. Sci. Total. Environ. doi: 10.1016/j.scitotenv.2016.12.180

Benidire L., Pereira S.I., Castro P.M., Boularbah A. (2016) Assessment of plant growth promoting bacterial populations in the rhizosphere of metallophytes from the kettara mine marrakech. Environ. Sci. Pollut. Res. Int. 23(21): 21751-21765.

Carlos M.H., Stefani P.V., Janette A.M., Melani M.S., Gabriela P.O. (2016) Assessing the effects of heavy metals in acc deaminase and iaa production on plant growth-promoting bacteria. Microbiol. Res. 188-189: 53-61.

Chauhan A.K., Maheshwari D.K., Kim K., Bajpai V.K. (2016) Termitarium-inhabiting Bacillus endophyticus TSH42 and Bacillus cereus TSH77 colonizing Curcuma longa L.: isolation characterization and evaluation of their biocontrol and plant-growth-promoting activities. Can. J. Microbiol. 62(10): 880-892.

Dworkin M., Foster J. (1958) Experiments with some microorganisms which utilize ethane and hydrogen. J. Bacteriol. 75: 592-601.

Edi-Premono M., Moawad A.M., Vleck P.L.G. (1996) Effect of phosphate solubilizing pseudomonas putida on the growth of maize and its survival in the rhizosphere. Indones. J. Agric. Sci. 11: 13-23.

Etesami H., Maheshwari D.K. (2018) Use of plant growth promoting rhizobacteria (PGPRs) with multiple plant growth promoting traits in stress agriculture: action mechanisms and future prospects. Ecotoxicol. Environ. Saf. 156: 225-246.

FAO (2009) How to feed the world in 2050. Insights from an expert meeting at FAO. 2050: 1-35.

Haiyambo D.H., Chimwamurombe P.M., Reinhold-Hurek B. (2015) Isolation and screening of Rhizosphere bacteria from grasses in East Kavango region of Namibia for plant growth promoting characteristics. Curr. Microbiol. 71(5): 566-571. 
Heydarian Z., Yu M., Gruber M., Glick B.R., Zhou R., Hegedus D.D. (2016) Inoculation of soil with plant growth promoting bacteria producing 1-aminocyclopropane-1-carboxylate deaminase or expression of the corresponding acids gene in transgenic plants increases salinity tolerance in Camelina sativa. Front. Microbiol. 7: 1966.

Holt J.G., Krieg N.R., Sneath P.H.A., Staley J.T., Williams S.T. (1994) Bergey's manual of determinative bacteriology.

Islam M.Z., Hossain M.T., Hossen F., Akter M.S., Mokammel M.A. (2016). In-vitro antioxidant and antimicrobial activity of Bougainvillea glabra flower. Res. J. Med. Plant 10: $228-236$.

Jasim B., Anish M.C., Shimil V., Jyothis M., Radhakrishnan E.K. (2015) Studies on plant growth promoting properties of fruit-associated bacteria from Elettaria cardamomum and molecular analysis of ACC deaminase gene. Appl. Biochem. Biotechnol. 177(1): 175-189.

Karnwal A. (2017) Isolation and identification of plant growth promoting rhizobacteria from maize (Zea mays L.) rhizosphere and their plant growth promoting effect on rice (Oryza sativa L.). J. Plant Prot. Res. 57(2): 144-151.

Karnwal A. (2019) Screening, isolation and characterization of culturable stress-tolerant bacterial endophytes associated with Salicornia brachiata and their effect on wheat (Triticum aestivum L.) and maize (Zea mays L.) growth. J. Plant Prot. Res. 59(3): 293-303.

Karnwal A., Dohroo A. (2018) Effect of maize root exudates on indole-3-acetic acid production by rice endophytic bacteria under influence of l-tryptophan. F1000Res. 7: 112.

Karnwal A., Kaushik P. (2011) Cytokinin production by fluorescent pseudomonas in the presence of rice root exudates. Arch. Phytopathol. Plant. Protect. 44(17): 1728-1735.

Khalifa A.Y., Alsyeeh A.M., Almalki M.A., Saleh F.A. (2016) Characterization of the plant growth promoting bacterium Enterobacter cloacae MSR1, isolated from roots of nonnodulating Medicago sativa. Saudi. J. Biol. Sci. 23(1): 79-86.

Kumar A., Verma J.P. (2018) Does plant-microbe interaction confer stress tolerance in plants: a review? Microbiol. Res. 207: 41-52.

Kumar P., Dubey R.C., Maheshwari D.K. (2012) Bacillus strains isolated from rhizosphere showed plant growth promoting and antagonistic activity against phytopathogens. Microbiol. Res. 167: 493-499.

Macauley H. (2015) Cereal crops: rice maize millet sorghum wheat. Feeding Africa: an action plan for African agricultural transformation: $1-36$. DOI: $10.1002 / y d .383$

Mahmood S., Daur I., Al-Solaimani S.G., Ahmad S., Madkour M.H., Yasir M., Hirt H., Ali S., Ali Z. (2016) Plant growth promoting rhizobacteria and silicon synergistically enhance salinity tolerance of mung bean. Front. Plant. Sci. 7: 876.

Masciarelli O., Llanes A., Luna V. (2014) A new PGPR coinoculated with bradyrhizobium japonicum enhances soybean nodulation. Microbiol. Res. 169(7-8): 609-615.

Myresiotis C.K., Vryzas Z., Papadopoulou-Mourkidou E. (2015) Effect of specific plant-growth-promoting rhizo- bacteria (PGPR) on growth and uptake of neonicotinoid insecticide thiamethoxam in corn (Zea mays L.) seedlings. Pest. Manag. Sci. 71: 1258-1266.

Nehra V., Saharan B.S., Choudhary M. (2016) Evaluation of Brevibacillus brevis as a potential plant growth promoting rhizobacteria for cotton (Gossypium hirsutum) crop. Springerplus. 5: 948.

Noori F., Etesami H., Najafi Zarini H., Khoshkholgh-Sima N.A., Hosseini Salekdeh G., Alishahi F. (2018) Mining alfalfa (Medicago sativa L.) nodules for salinity tolerant non-rhizobial bacteria to improve growth of alfalfa under salinity stress. Ecotoxicol. Environ. Saf. 162: 129-138.

Passari A.K., Mishra V.K., Leo V.V., Gupta V.K., Singh B.P. (2016) Phytohormone production endowed with antagonistic potential and plant growth promoting abilities of culturable endophytic bacteria isolated from Clerodendrum colebrookianum Walp. Microbiol. Res. 193: 57-73.

Perrig D., Boiero M.L., Masciarelli O.A., Penna C., Ruiz O.A., Cassan F.D., Luna M.V. (2007) Plant-growth-promoting compounds produced by two agronomically important strains of Azospirillum brasilense and implications for inoculant formulation. Appl. Microbiol. Biotechnol. 75(5): 1143-1150.

Sarkar A., Pramanik K., Mitra S., Soren T., Maiti T.K. (2018) Enhancement of growth and salt tolerance of rice seedlings by ACC deaminase-producing Burkholderia sp. MTCC 12259. J. Plant. Physiol. 231: 434-442.

Schwyn B., Neilands J.B. (1987) Universal chemical assay for the detection and determination of siderophores. Analyt. Biochem. 160: 47-56.

Silva H.S.A., Romeiro R.D.S., Mounteer A. (2003) Development of a root colonization bioassay for rapid screening of rhizobacteria for potential biocontrol agents. J. Phytopath. 151(1): 42-46.

Taghavi S., Wu X., Ouyang L., Zhang Y.B., Stadler A., McCorkle S., Zhu W., Maslov S., van der Lelie D. (2015) Transcriptional responses to sucrose mimic the plantassociated life style of the plant growth promoting endophyte Enterobacter sp. 638. PLoS. One. 10(1): e0115455.

Tak H.I., Ahmad F., Babalola O.O. (2013) Advances in the application of plant growth-promoting rhizobacteria in phytoremediation of heavy metals. Rev. Environ. Contam. Toxicol. 223: 33-52.

Torres M., Dessaux Y., Llamas I. (2019) Saline environments as a source of potential quorum sensing disruptors to control bacterial infections: a review. Mar. Drugs. 17(3).

Ullah I., Al-Johny B.O., Al-Ghamdi K.M.S., Al-Zahrani H.A.A., Anwar Y., Firoz A., Al-Kenani N., Almatry M.A.A. (2019) Endophytic bacteria isolated from Solanum nigrum L., alleviate cadmium (Cd) stress response by their antioxidant potentials including sod synthesis by soda gene. Ecotoxicol. Environ. Saf. 174: 197-207.

Vaishnav A., Kumari S., Jain S., Varma A., Tuteja N., Choudhary D.K. (2016) PGPR-mediated expression of salt tolerance gene in soybean through volatiles under sodium nitroprusside. J. Basic. Microbiol. 56: 1274-1288. 
Vejan P., Abdullah R., Khadiran T., Ismail S., Nasrulhaq Boyce A. (2016) Role of plant growth promoting rhizobacteria in agricultural sustainability - a review. Molecules 21(5). doi: 10.3390/molecules21050573

Yadav S., Kaushik R., Saxena A.K., Arora D.K. (2011) Diversity and phylogeny of plant growth-promoting bacilli from moderately acidic soil. J. Basic. Microbiol. 51(1): 98-106.
Yasin M. (1998) Effectiveness of chemical and biotic methods for reclamation of saline-sodic soil. Pak. J. Soil. Sci. 15: 179-182. 